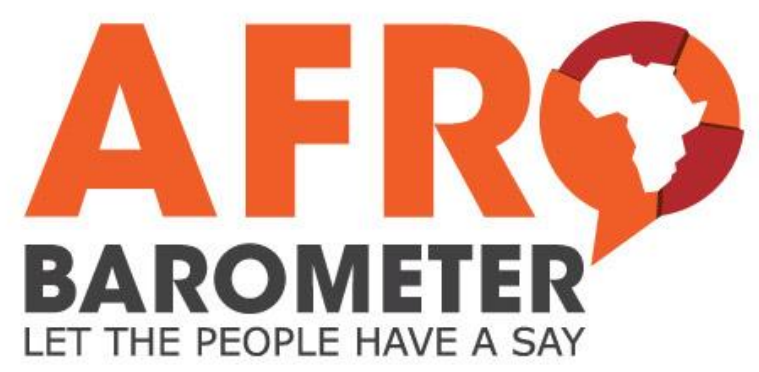

Working Paper No. 173

\title{
Explaining South African xenophobia
}

by Christopher Claassen | June 2017 


\section{ATRQ \\ BAROMETER \\ LET THE PEOPLE HAVE A SAY}

\section{Working Paper No. 173}

\section{Explaining South African xenophobia}

\section{by Christopher Claassen | June 2017}

Christopher Claassen is a lecturer in the School of Social and Political Sciences at the University of Glasgow. Email: Christopher.Claassen@glasgow.ac.uk.

\section{Abstract}

After widespread violence in 2008 and 2015, South Africa is now clearly one of most hostile destinations in the world for African migrants. Existing research on the determinants of South African xenophobia has focused on developing and advancing theories, with little attention paid to testing which theories, if any, actually account for mass xenophobia. This is the goal of this paper. By combining individual-level Afrobarometer survey items with municipal-level census indicators, we produce a rich, quantitative data set of numerous factors that have been proposed as determinants of South African xenophobia. The results of multilevel regression analyses show support for the explanations of poverty, relative deprivation, frustration with government, and social mobilization, with mixed evidence for resource competition. Taken together, the results point toward a mechanism of scapegoating, where frustrations and hopelessness produce aggression that is targeted at African immigrants. 


\section{Introduction}

South Africa now has the unfortunate reputation as one of the more hostile destinations in the world for African migrants. Widespread attacks targeting foreigners took place in May 2008, killing 62 people and making international headlines. Another wave of violence occurred in April 2015, leading to an outcry across Africa and the recall of the Nigerian ambassador. These are not attacks caused by small bands of provocateurs or criminals; both qualitative and quantitative evidence suggests widespread participation in, and support for, the violence in the affected communities (Claassen, 2014). Indeed, a number of commentators have remarked on the elevated levels of xenophobia observed in South Africa (see, for example, Mattes, Taylor, McDonald, Poore, \& Richmond, 1999), with African nationals, in particular, facing everyday hostility and violence (Everatt, 2010). Thus, rather than a case of rare and sporadic attacks disturbing otherwise peaceful relations between locals and African immigrants, South African xenophobia appears to take the form of widespread antipathy and intolerance punctuated by acts of hostility and violence.

South African xenophobia has national and regional political consequences. The violence that took place in 2008 and 2015, as well as the hate crimes that occur with everyday regularity, present a pressing human rights concern. Furthermore, as Landau $(2011,2012)$ has noted, such levels of intergroup hostility are a symptom of a deep social and political malaise. Finally, as the sharp international reaction to the 2015 attacks indicates, South African xenophobia now constrains the country's international relations, particularly within Africa.

This paper investigates the determinants of South African xenophobia. Despite a great deal of reflection, commentary, and research by government, civil society, and scholars, ${ }^{1}$ we have a poor understanding of the factors that influence and shape hostility toward African immigrants. The problem is not a scarcity of explanations, but an overabundance. With up to a dozen explanations proffered by experts, we have little idea what actually causes hostility toward immigrants. Moreover, the laundry list of possibilities gives little clue whether some causal factors are contingent on others, as is often the case in social processes. ${ }^{2}$

To address South African xenophobia, we need to understand it. And to understand it, we require data on the attitudes of a large representative sample of South Africans toward African migrants. After all, a widespread syndrome of mass xenophobia is a hallmark of the South African case, and is probably the wellspring of the 2008 and 2015 violence. A few researchers have already examined mass attitudes and behaviors, but either use convenience samples that are not representative of the public at large (Claassen, 2016; Misago, 2012) or restrict the analysis to univariate and bivariate summaries, which are insufficient to test causal explanations for xenophobia (Southern African Migration Project, 2008). Other existing research relies on qualitative interviews with small numbers of informants (South African Human Rights Commission, 2010; Human Sciences Research Council, 2008; Misago, Monson, Polzer, \& Landau, 2010; and Hickel, 2014), analysis of media coverage (Monson \& Arian, 2012), or the interpretation of social discourses (Nieftagodien, 2012; Landau, 2011).

\footnotetext{
${ }^{1}$ For example, South African Human Rights Commission, 2010; Parliament of the Republic of South Africa, 2008; and Human Sciences Research Council, 2008.

${ }^{2}$ See, for example, this conclusion by Everatt (2010, p. 1): "It is argued here that a combination of deep structural social, economic and spatial inequalities, an on-going reliance on cheap labor, housing shortages, township retail competition, racism, a history of the use of violence to advance sectional interests and a traumatically scarred national psyche combined in early 2008 with a desperately low national mood as the economy seemed to be in free-fall and the ruling party was in the midst of factional splitting, to create ripe conditions for the xenophobic outburst." The true explanation for xenophobia may well be listed in there somewhere, but where?
} 
The goal of this paper is to test a host of competing explanations for xenophobia using 2011 public opinion survey data from Afrobarometer. Being a large representative sample of more than 2,000 South Africans, this survey allows us to construct a picture of xenophobia and then to carefully examine the factors associated with variations in the picture. This survey is additionally useful because it includes two precisely worded questions on willingness to participate in collective action against African immigrants. These questions ask respondents to consider an anti-immigrant behavior that is aggressive enough to separate the real xenophobes in the sample from the uncertain, and the uncertain from the genuinely tolerant. It is also the behavior observed in 2008 and 2015, which means that it is both salient and meaningful to survey respondents.

Given the diversity of explanations that have been proposed for South African xenophobia, involving psychological, social, and political processes, we require measures of a wide variety of explanatory variables: subjective and objective, as well as internal and contextual. We thus bolster the individual-level variables included in the survey data set with information from the 2011 census on the economic and demographic conditions in the local municipality in which the respondent lived. The result is a rich data set of contextual conditions, perceptions thereof, socio-political attitudes, and xenophobic aggression.

In the next section, I discuss South African xenophobia, the forms it takes, its depth and breadth, the victims and participants in the 2008 and 2015 attacks, as well as the official and popular reactions. The third section reviews research on xenophobia in South Africa as well as the broader literature on hostility and violence toward minority outgroups, identifying six major theories and drawing out testable hypotheses. The fourth section describes the data, dependent and independent variables, and methods. The fifth section presents the results of multilevel regression analyses before the final section discusses and offers some concluding comments.

\section{Xenophobia in South Africa}

The post-apartheid era in South Africa has been marked by a steady undercurrent of xenophobia, both attitudinal and behavioral. Data from the 1995 World Values Survey showed that South Africans were the most xenophobic nation of the 18 included in the sample (Mattes et al., 1999). A 1998 survey found similarly xenophobic sentiments: Large majorities of the sample of South Africans supported policy proposals that foreigners should carry identification at all times (72\%) and that South Africa's border fence should be electrified (66\%) (Crush, 2001). Eight years later, in 2006, xenophobic attitudes were just as prevalent: A survey conducted that year found that almost half of the South African sample wanted foreign nationals, regardless of their legal status, to be deported (Southern African Migration Project, 2008). The results of this same survey showed that antipathy to immigrants is not restricted to certain South African ingroups, or certain national outgroups: The proportion of the sample holding a favourable view of immigrants did not exceed $26 \%$, no matter whether the sample was restricted to blacks or whites, or whether respondents were queried about immigrants from Africa, Europe, or North America.

African migrants are, however, the immigrant group most likely to experience the behavioral consequences of xenophobia. Everyday discrimination is frequently encountered, especially by nationals of Central and West African countries (Morris, 1998; Dodson, 2010). Vigilante attacks on immigrant individuals, particularly shopkeepers, are disturbingly common (Harris, 2001; Charman \& Piper, 2012).

One such incident of mob vigilantism occurred on the evening of 11 May 2008 in Alexandra township in Johannesburg. ${ }^{3}$ A crowd in the largely Zulu-speaking Sector 2 of Alexandra gathered and began chanting anti-immigrant slogans such as "Phansi amakwerekwere" Zulu for "Down with foreigners" (Nyar, 2010). Several smaller groups split off and went door to

\footnotetext{
${ }^{3}$ This brief account draws heavily on the more detailed discussion in Monson and Arian (2012).
} 
door searching for foreigners. Anyone who could not pass their test, to provide the Zulu word for "elbow," was beaten.

In contrast to previous incidents, the violence only intensified over the following days. By 14 May, Alexandra was in uproar, with thousands of residents attacking anyone thought to be foreign, looting and destroying their homes and shops, and clashing with police. This pattern of violence then spread to other townships in and around Johannesburg, including Diepsloot, Tembisa, and Thokoza. By the following week, violence was occurring in downtown Johannesburg and parts of Cape Town.

This xenophobic violence 4 - as it is now called - finally abated after three weeks, leaving 62 people dead, 670 wounded, and 100,000 displaced (Misago et al., 2010). Zimbabweans and Mozambicans were particularly well-represented among the victims (Monson \& Arian, 2012). Twenty-one of the dead were, however, South African nationals, perhaps mistaken for foreigners, punished for not participating in the violence, or the victims of police aggression.

Official reaction was slow in coming. Government then denied that xenophobia played a role in the violence, instead blaming criminals or "third forces" (Landau, 2011). A flurry of research and policy papers followed, from both the academy and government (for example, South African Human Rights Commission, 2010; Human Sciences Research Council, 2008). Yet policy recommendations were not heeded, or did not make a difference, because between the end of the 2008 attacks and April 2015, 350 foreigners were killed because of their perceived national origins (Hall, 2015). And in April 2015, spurred on by inflammatory remarks from the Zulu monarch, King Goodwill Zwelithini - who referred to African foreigners as "lice" - another widespread wave of attacks took place (Hall, 2015). The violence began this time in Durban before spreading to Johannesburg. Once again, townships, shantytowns, and inner cities were the affected areas. Although the death toll was lower than in 2008, with eight deaths attributable to xenophobia, the international reaction was more marked (Essa, 2015). The UN Security Council issued a sharp criticism, as did the leaders of Zimbabwe, Mozambique, and Malawi, while Nigeria, South Africa's rival for continental dominance, recalled its ambassador (Essa \& Patel, 2015).

\section{Theory and hypotheses}

Scholars have not been shy in advancing explanations for the elevated levels of violence and hostility toward African immigrants that became apparent in South Africa after 2008, creating an extensive literature. ${ }^{5}$ Drawing on this body of research - supplemented, when necessary, by forays into the vast social science literature on hostility and violence toward outgroups - this section outlines six theories that have been, or could be, advanced to explain South African xenophobia. These are: (1) resource competition, (2) poverty, (3) relative deprivation, (4) frustration with government, (5) mobilization, and (6) symbolic threat.6

Resource competition. According to perhaps the most renowned theory of intergroup conflict, tensions and violence are a function of intergroup competition over scarce resources, with competition and conflict increasing when economic conditions deteriorate. Classic statements of this theory are "realistic conflict" in social psychology (Sherif, 1966) and "ethnic competition" in sociology (Bonacich, 1976; Olzak, 1992). Dancygier (2010) has linked such dynamics with anti-immigrant violence in Europe. Many studies of South African

\footnotetext{
${ }^{4}$ Such episodes are perhaps better characterized as instances of a more general phenomenon: the communal or ethnic riot. See Horowitz (2001) and Claassen (2014).

${ }^{5}$ See Dodson (2010) for an incisive review of the research on xenophobia before 2008.

${ }^{6}$ Explanations that focus solely on the commission of violence, without taking xenophobic motives into account, such as the "culture of violence" or lack of respect for the rule of law, are not considered here because our goal is to explain xenophobia. Explanations that invoke xenophobia as a causal factor also cannot be considered here as xenophobia is our dependent variable.
} 
xenophobia also use resource competition as an explanation, with two resources, in particular, identified as possible flashpoints: jobs and government housing (Human Sciences Research Council, 2008; Centre for the Study of Violence and Reconciliation, 2008; Everatt, 2010; Steinberg, 2008; Misago, 2012). The hypothesis is thus:

$\mathrm{H1}$ : Competition, for either jobs or housing, with African immigrants increases xenophobia.

Poverty. Another longstanding hypothesis in the social sciences holds that hostility and violence toward outgroups is triggered by economic deprivation, or poverty (Hovland \& Sears, 1940; Lipset, 1960). Poverty is usually linked to outgroup aggression using the mechanism of scapegoating. This mechanism holds that poverty produces frustration, and consequently aggression, with aggression then displaced onto some innocent but weak third party (Dollard, Miller, Doob, Mowrer, \& Sears, 1939). Everatt (2010) has applied this explanation to the South African case, although quantitative research finds that the electoral wards affected by xenophobia were not, in fact, the poorest (Fauvelle-Aymar \& Segatti, 2012). We will investigate this hypothesis further, using both personal and contextual measures:

H2: Poverty increases xenophobia.

Relative deprivation. In a refinement of the "poverty begets conflict" argument, scholars have argued that frustration, and thus aggression, are functions of expected welfare as much as actual deprivation. This relative deprivation theory is now well-established, with both personal (Gurr, 1970) and "fraternal" (or intergroup) (Runciman, 1966) variations having been advanced. Relative deprivation theory also utilizes the mechanism of frustration-aggression to link perceptions of conditions and conflict. A number of studies of South African xenophobia have used arguments based on relative deprivation. Inequality (Everatt, 2010), the "J-curve" of thwarted, rising expectations (Centre for the Study of Violence and Reconciliation, 2008; Dodson, 2010), a "V-curve" balancing relative deprivation and relative gratification (Dambrun, Taylor, McDonald, Crush, \& Méot, 2006), a "moral economy" of unfair competition (Hickel, 2014), and beliefs that locals deserve more than immigrants (Claassen, 2016) have all been advanced as determinants of hostility toward immigrants. We thus hypothesize that:

\section{H3: Relative deprivation increases xenophobia.}

Frustration with government. A recurring theme in the literature is the claim that South African xenophobia is a result of accumulated frustrations with government. Some studies emphasize the insufficient provision of government services, or "service delivery," while others underline the perceived disinterest of government and the resulting lack of voice experienced by many communities (Human Sciences Research Council, 2008; Centre for the Study of Violence and Reconciliation, 2008; Morris, 1998). In both cases, a frustration-aggression or scapegoating mechanism is again implicated.

H4: Frustration with government increases xenophobia.

Mobilization. Anti-immigrant violence requires collective action, and one of the foremost explanations for participation in collective action is the extent to which individuals are subject to mobilizing forces. The first of these is social ties to other individuals in the community (McAdam, 1986; Snow, Zurcher, \& Ekland-Olson, 1980). One of the most original studies of the 2008 attacks identified township community policing meetings as the fora where community links drew participants into the attacks (Misago, 2012). Although embeddedness in social networks is typically used as an explanation for behavior, it has also been used to account for attitudinal constraint (Huckfeldt, Beck, Dalton, \& Levine, 1995). 
Social ties to the community can thus be expected to produce xenophobic behavior as well as xenophobic attitudes.

A second source of xenophobic mobilization comes from political leaders. Indeed, the broader literature on conflict argues that leaders might face incentives to instigate intergroup tensions to the extent that intergroup conflict can be used as a vehicle for the pursuit of political and economic ends (Bates, 1974; Wilkinson, 2004). Although FauvelleAymar and Segatti (2012) find that wards dominated by the African National Congress (ANC) - which are less competitive than wards with a stronger opposition presence - were more likely to be struck by violence in 2008 , South African leaders have repeatedly made xenophobic public statements (Neocosmos, 2006; Misago et al., 2010; Dodson, 2010). We thus re-examine this hypothesis using both municipal-level and individual-level data.

H5: Social and political mobilization increases xenophobia.

Symbolic threat. In developed-world contexts, immigrants may adhere to different cultural and religious traditions than the majority of natives, and are thus thought to pose symbolic threats to national and cultural identity (Huddy \& Sears, 1995). These symbolic threats have been shown to be a major determinant of xenophobia and opposition to immigration (McLaren, 2003; Sniderman, Hagendoorn, \& Prior, 2004). According to this theory, immigrants are threatening to the extent that they are culturally distinct from natives and to the extent that natives hold strong national identities. While the cultural and religious differences between Zimbabweans or Mozambicans, on the one hand, and most South Africans, on the other, are far less pronounced, the heightened xenophobia directed against immigrants from more culturally and geographically distal nations such as Nigeria and Eritrea has convinced some researchers that symbolic threats to culture and identity play a role in South African xenophobia, too (Doson, 2010; Neocosmos, 2006).

H6: Symbolic threat to ingroup identity increases xenophobia.

\section{Methods}

\section{Data}

The data come from a public opinion survey of a representative sample of 2,399 South African adult residents, which was conducted by Afrobarometer in 2011 . These individuallevel data are coupled with contextual data on the demographics and economic conditions of the 185 local municipalities in which survey respondents were located.7

\section{Dependent variable}

The 2011 wave of the Afrobarometer survey is of interest because it includes two items tapping respondents' desire and willingness to take part in collective action against African immigrants. The items are worded as follows: "How likely is it that you would take part in action to prevent people who have come here from other countries in Africa from (1) moving into your neighbourhood? (2) operating a business in your area?"8 These questions thus restrict respondents' attention to the outgroup of interest for this study. And although they measure attitudes, these survey items focus on one of the most concerning aspects of South African xenophobia: the widespread participation observed during the anti-immigrant attacks of 2008 and 2015. The two items are correlated at 0.80 , which indicates that they can be meaningfully combined into a single measure of xenophobic aggression. Our dependent

\footnotetext{
${ }^{7}$ Local municipalities are the smallest and most local tier in the South African administrative hierarchy. The 185 municipalities (out of 234) from which respondents were sampled vary in size from around 12,000 to more than 4 million inhabitants.

8 The two items have four-point response sets that range from "very likely" to "very unlikely."
} 
variable is thus an additive scale of the two items, which we then standardize to range from 0 to 1.

Table 1 shows the levels of xenophobia across the two items and the whole scale, and for each racial group as well as the whole sample. Despite the aggressive nature of the items, a considerable number of respondents, $32 \%$ and $35 \%$, agree that they would in fact take part in anti-immigrant collective action. The same two survey items were included in previous Southern African Migration Project surveys, conducted in 1997, 1999, and 2006. Very similar proportions of respondents (between $30 \%$ and $34 \%$ ) agreed with these two items over those three surveys. Table 1 also shows that white and coloured respondents exhibit less xenophobia than black and Asian respondents - at least before adjusting for differences in geographic location, poverty, and so on. These differences are, however, modest, while xenophobia is remarkably high for all racial groups. In sum, these descriptive results highlight the extraordinary depth of South African xenophobia, its breadth across racial groups, and its considerable stability over time.

\section{Table 1: Levels of xenophobia in the sample}

\begin{tabular}{lccc}
\hline Sample & $\begin{array}{c}\text { Oppose foreigners moving } \\
\text { into neighbourhood } \\
\text { (\% agree) }\end{array}$ & $\begin{array}{c}\text { Oppose foreigners } \\
\text { operating business in area } \\
\text { (\% agree) }\end{array}$ & $\begin{array}{c}\text { Xenophobic aggression } \\
\text { scale (1-7) } \\
\text { (mean) }\end{array}$ \\
\hline Black & 34 & 37 & 3.35 \\
Asian & 37 & 40 & 3.51 \\
Coloured & 21 & 26 & 2.96 \\
White & 26 & 31 & 3.03 \\
Whole sample & 32 & 35 & 3.28 \\
\hline
\end{tabular}

Source: Afrobarometer Round 5 (2011)

\section{Explanatory variables}

After combining the survey and census data, 24 measures of potential explanatory factors are available. ${ }^{9}$ Labor-market competition is measured at the individual level using respondents' level of education ${ }^{10}$ and labor-market status, ${ }^{11}$ and at the contextual level with the municipal unemployment rate of the ingroup. 12 Housing competition is measured with an indicator for whether the respondent lived in informal housing and the proportion of the ingroup in the municipality living in informal housing. The degree of resource competition is expected to be a function of the size of the immigrant community, so we include the percentage of the municipal population born elsewhere in Africa.

Poverty is measured using both individual and contextual measures. The latter is the percentage of ingroup households in the municipality who earn less than 20,000 South African rand a year. There are two individual measures. The first is an expanded version of the

\footnotetext{
${ }^{9}$ We use the expectation maximization algorithm to impute missing values. Variables for which values are missing are: age (1.6\% missing), news source (0.04\% missing), and party support ( $12.3 \% \mathrm{missing})$.

${ }^{10}$ Nominal variable with the following five categories: less than primary, completed primary, some secondary, completed secondary, and post-secondary level of education.

${ }^{11}$ Nominal variable with the following three categories: working, looking for work, or not in the labor force at the time of the survey.

12 "Ingroup" for all municipal-level variables varies by sample. For analyses of the whole sample, it refers to the population of the municipality; for the black sample, the black population; and for the white sample, the white population. So the ingroup unemployment rate for analyses of the black sample is the unemployment rate among black individuals in the municipality.
} 
Afrobarometer Lived Poverty Index, a scale composed of six items asking respondents to what extent they experienced a lack of food, water, medicine, heating fuel, money, or electricity in the past year. The second is a scale composed of another six items asking respondents to evaluate personal and national economic conditions. ${ }^{13}$

Personal relative deprivation is measured at the individual level using a survey item asking respondents to compare their personal economic well-being to that of other South Africans, and at the contextual level by the within-group Gini coefficient. ${ }^{14}$ Fraternal relative deprivation is measured using the between-race group Gini coefficients. ${ }^{15}$

Frustration with government is measured at the contextual level by service delivery: the average proportion of ingroup households in the municipality that receive electricity and water services. At the individual level, we have two subjective measures: first, a government performance evaluation scale that combines appraisals of policy delivery across 18 areas, 16 and second, a two-item external political efficacy scale asking respondents whether local and national elected officials "listen to people like you."

We have two measures of respondents' ties to their communities. First, we include an indicator for whether the respondent attended community meetings in the previous year, which Misago (2012) found to be the venues in the townships where violence was organized in 2008. Second, we have a scale of participation in collective political action, composed of eight indicators for whether the respondent took part in protests, strikes, boycotts, etc. Political mobilization is then measured using three variables. The first is the proportion of the municipal seats won by opposition parties in 2011 , which reflects the competitiveness of the local electoral arena. The second is the respondent's stated support for a particular political party. ${ }^{17}$ And because of the prevalence of xenophobic statements from political leaders, we include a third measure: whether the respondent watched, listened to, or read the news on a daily basis. ${ }^{18}$

Finally, according to the theory of symbolic threat, the strength of one's national identity should result in a perception that outsiders are more threatening, and thus an increased level of hostility to such outsiders. We use an index of six items from Afrobarometer as a measure of respondents' attachment to the national identity. In addition, because the minority race groups - coloured, Asian, and white - are more culturally distant from African immigrants than black South Africans are, and would be particularly prone to perceiving such immigrants as a symbolic threat, we use group identity as a second measure of symbolic threat.

\footnotetext{
${ }^{13}$ The six economic evaluation items are used as a single scale. This is preferable because the scale is reliable and one measure provides a simpler interpretation than using all six. However, in additional analyses not reported here, I include the six separate items rather than the single scale and find that the personal and national prospective measures have a strong negative effect on xenophobia, with the other four items showing zero to weakly negative effects.

${ }^{14}$ The Gini coefficient is a measure of income inequality. Census data from 2011 on income distributions are used to construct this measure. For the white and black samples, the measure is within groups; it only uses income data for these race groups.

${ }^{15}$ In other words, the inequality between the average income of each race group.

${ }^{16}$ The survey instrument included a further item, asking for respondents' evaluations of immigration policy. This is excluded from the scale due to its similarity to the dependent variable.

${ }^{17}$ Three-category nominal variable: supports ANC, supports opposition party, or does not support any party.

${ }^{18}$ This indicator is coded as 1 if respondents stated that they obtained news on a daily basis from any of the following media: newpapers, TV, radio, or Internet.
} 


\section{Empirical strategy}

As the data set includes variables at two levels of analysis - individual and municipal - we use multilevel linear regression to test the hypotheses. ${ }^{19}$ Each hypothesis is tested using at least two models. The first adds the independent variables corresponding to the theory at hand to a model with a few basic demographic and geographic controls: the respondent's age group, gender, rural or urban status, and the logarithm of the municipal population. The second includes all independent variables in the model.

Because of the important role played by race in the formation of South African social and political attitudes, we run each of these models separately on the black $(N=1,534)$ and white $(N=413)$ subsamples, in addition to the full sample. This is similar to allowing race to interact with all model parameters.

\section{Results}

\section{Resource competition}

Table 2 shows the tests of the resource competition hypothesis across nine models. The first three pertain to the full sample; the next three restrict the sample to black respondents, while the final three models use the sample of white respondents. Within each sample, the resource competition variables are included alongside the set of basic control variables in two models and the full set of independent variables in a third model.

The results show that labor-market status has somewhat unexpected effects on xenophobia. It is not South Africans who are unemployed and looking for work who are most hostile to immigrants, but rather those who are not in the labor force because they are no longer looking for work. The results in Table 2 indicate that although respondents who are employed exhibit lower levels of xenophobia compared with those who are neither employed nor looking for work (the omitted category), this effect does not survive the inclusion of the full set of control variables. Nor does it extend to the white sample of respondents. In fact, both employment and unemployment are associated with lower levels of xenophobia, which suggests that the most meaningful comparison is between respondents who are engaged in the labor market, either by working or looking for work, and respondents who are disengaged. Models 2, 5, and 8 thus switch out the indicators for employment and unemployment for the indicator of disengagement from the labor market. In the black sample, although not in the full or white samples, this indicator has a significant positive effect on xenophobia.

To explore these results further, I examine how the effect of labor-market status interacts with race and age. Because tabulated results of three-way interactions are exceedingly difficult to interpret, I instead plot the predicted effects of a model using the full sample, the set of basic controls, and an interaction between labor-market status, race, and age group (Figure 1 below). We see that, firstly, the effects of participating in the labor force (indicated with the darker line and filled points) do not vary much by age, either for black respondents (left panel) or white respondents (right panel). The effects of being disengaged from the labor market, in contrast, vary dramatically by age and race. For black respondents, being disengaged from the labor market leads to increased levels of xenophobia in the 25- to 49year-old age band - the prime working years. For white respondents, the effects are clouded by the large error bars that result from the smaller samples, but if anything, being disengaged from the labor market reduces xenophobia.

It thus appears that labor-market competition, of a kind, can account for the strong positive effect of non-participation in the labor market on xenophobia among black South Africans. It is not individuals actively competing with foreign nationals who express hostility, but those who have given up competing.

\footnotetext{
${ }^{19}$ See, for example, Gelman and Hill (2007).
} 
Table 2: The effects of resource competition on xenophobia

\begin{tabular}{|c|c|c|c|c|c|c|c|c|c|}
\hline \multirow{3}{*}{$\begin{array}{l}\text { Sample: } \\
\text { Other covariates: }\end{array}$} & Model 1 & Model 2 & Model 3 & Model 4 & Model 5 & Model 6 & Model 7 & Model 8 & Model 9 \\
\hline & \multicolumn{3}{|c|}{ Full } & \multicolumn{3}{|c|}{ Black } & \multicolumn{3}{|c|}{ White } \\
\hline & Basic & Basic & All & Basic & Basic & All & Basic & Basic & All \\
\hline Unemployed but looking & $\begin{array}{l}-.02 \\
(.02)\end{array}$ & & $\begin{array}{l}-.02 \\
(.02)\end{array}$ & $\begin{array}{l}-.04 \\
(.02)\end{array}$ & & $\begin{array}{l}-.05^{*} \\
(.02)\end{array}$ & $\begin{array}{l}.07 \\
(.06)\end{array}$ & & $\begin{array}{c}.06 \\
(.06)\end{array}$ \\
\hline Employed & $\begin{array}{l}-.04 * \\
(.02)\end{array}$ & & $\begin{array}{c}-.03 \\
(.02)\end{array}$ & $\begin{array}{r}-.06^{*} \\
(.03)\end{array}$ & & $\begin{array}{l}-.05 \\
(.02)\end{array}$ & $\begin{array}{c}.04 \\
(.04)\end{array}$ & & $\begin{array}{c}.03 \\
(.04)\end{array}$ \\
\hline Not in the labor force & & $\begin{array}{l}.03 \\
(.02)\end{array}$ & & & $\begin{array}{l}.05^{*} \\
(.02)\end{array}$ & & & $\begin{array}{l}-.05 \\
(.04)\end{array}$ & \\
\hline Education: less than primary & $\begin{array}{l}.14^{* *} \\
(.04)\end{array}$ & & $\begin{array}{l}.12 * * \\
(.04)\end{array}$ & $\begin{array}{l}.20^{*} \\
(.08)\end{array}$ & & $\begin{array}{l}.20^{*} \\
(.08)\end{array}$ & $\begin{array}{c}.06 \\
(.09)\end{array}$ & & $\begin{array}{c}.05 \\
(.09)\end{array}$ \\
\hline Education: primary & $\begin{array}{c}.07 \\
(.04)\end{array}$ & & $\begin{array}{c}.06 \\
(.04)\end{array}$ & $\begin{array}{c}.13 \\
(.08)\end{array}$ & & $\begin{array}{l}.13 \\
(.08)\end{array}$ & $\begin{array}{l}-.04 \\
(.06)\end{array}$ & & $\begin{array}{l}-.03 \\
(.06)\end{array}$ \\
\hline Education: some secondary & $\begin{array}{c}.07 \\
(.04)\end{array}$ & & $\begin{array}{c}.07 \\
(.04)\end{array}$ & $\begin{array}{c}.13 \\
(.08)\end{array}$ & & $\begin{array}{c}.14 \\
(.08)\end{array}$ & $\begin{array}{l}-.00 \\
(.05)\end{array}$ & & $\begin{array}{c}.00 \\
(.05)\end{array}$ \\
\hline Education: secondary & $\begin{array}{l}.10^{*} \\
(.04)\end{array}$ & & $\begin{array}{l}.10^{*} \\
(.04)\end{array}$ & $\begin{array}{l}.16 \\
(.08)\end{array}$ & & $\begin{array}{l}.16^{*} \\
(.08)\end{array}$ & $\begin{array}{c}.03 \\
(.05)\end{array}$ & & $\begin{array}{c}.00 \\
(.05)\end{array}$ \\
\hline Total municipal unemployment rate & $\begin{array}{c}.00 \\
(.02)\end{array}$ & $\begin{array}{c}.00 \\
(.02)\end{array}$ & $\begin{array}{l}-.04 \\
(.04)\end{array}$ & & & & & & \\
\hline Black municipal unemployment rate & & & & $\begin{array}{l}-.05 \\
(.03)\end{array}$ & $\begin{array}{l}-.06 \\
(.03)\end{array}$ & $\begin{array}{l}-.07 \\
(.04)\end{array}$ & & & \\
\hline White municipal unemployment rate & & & & & & & $\begin{array}{l}-.20 \\
(.19)\end{array}$ & $\begin{array}{l}-.21 \\
(.19)\end{array}$ & $\begin{array}{l}-.26 \\
(.22)\end{array}$ \\
\hline Informal housing & $\begin{array}{c}.01 \\
(.02)\end{array}$ & $\begin{array}{c}.03 \\
(.02)\end{array}$ & $\begin{array}{l}-.01 \\
(.02)\end{array}$ & $\begin{array}{l}-.00 \\
(.02)\end{array}$ & $\begin{array}{c}.01 \\
(.02)\end{array}$ & $\begin{array}{l}-.01 \\
(.02)\end{array}$ & $\begin{array}{l}-.00 \\
(.09)\end{array}$ & $\begin{array}{l}-.00 \\
(.08)\end{array}$ & $\begin{array}{c}.01 \\
(.08)\end{array}$ \\
\hline Total municipal informal housing rate & $\begin{array}{c}.00 \\
(.02)\end{array}$ & $\begin{array}{c}.00 \\
(.02)\end{array}$ & $\begin{array}{c}.01 \\
(.02)\end{array}$ & & & & & & \\
\hline Black municipal informal housing rate & & & & $\begin{array}{l}-.01 \\
(.02)\end{array}$ & $\begin{array}{l}-.01 \\
(.02)\end{array}$ & $\begin{array}{l}-.01 \\
(.02)\end{array}$ & & & \\
\hline Log \% foreign in municipality & $\begin{array}{l}-.00 \\
(.02)\end{array}$ & $\begin{array}{l}-.00 \\
(.02)\end{array}$ & $\begin{array}{l}.00 \\
(.02)\end{array}$ & $\begin{array}{l}-.02 \\
(.02)\end{array}$ & $\begin{array}{l}-.02 \\
(.02)\end{array}$ & $\begin{array}{l}.00 \\
(.03)\end{array}$ & $\begin{array}{l}-.01 \\
(.05)\end{array}$ & $\begin{array}{l}-.01 \\
(.05)\end{array}$ & $\begin{array}{l}-.02 \\
(.08)\end{array}$ \\
\hline Akaike Information Criterion & 1772.24 & 1754.40 & 1771.12 & 1086.31 & 1066.38 & 1104.25 & 370.57 & 342.39 & 420.25 \\
\hline$N$ respondents & 2399 & 2399 & 2399 & 1534 & 1534 & 1534 & 413 & 413 & 413 \\
\hline$N$ municipalities & 185 & 185 & 185 & 157 & 157 & 157 & 54 & 54 & 54 \\
\hline Variance of municipal intercepts & .02 & .02 & .02 & .02 & .02 & .01 & .03 & .03 & .03 \\
\hline Variance of residuals & .09 & .09 & .09 & .11 & .11 & .10 & .06 & .06 & .05 \\
\hline
\end{tabular}

${ }^{* * *} p<0.001, * * p<0.01,{ }^{*} p<0.05$. Standard errors in parentheses. All variables standardized to range from 0 to 1 . 
Figure 1: The effects of labor-force participation by age and race

Black respondents

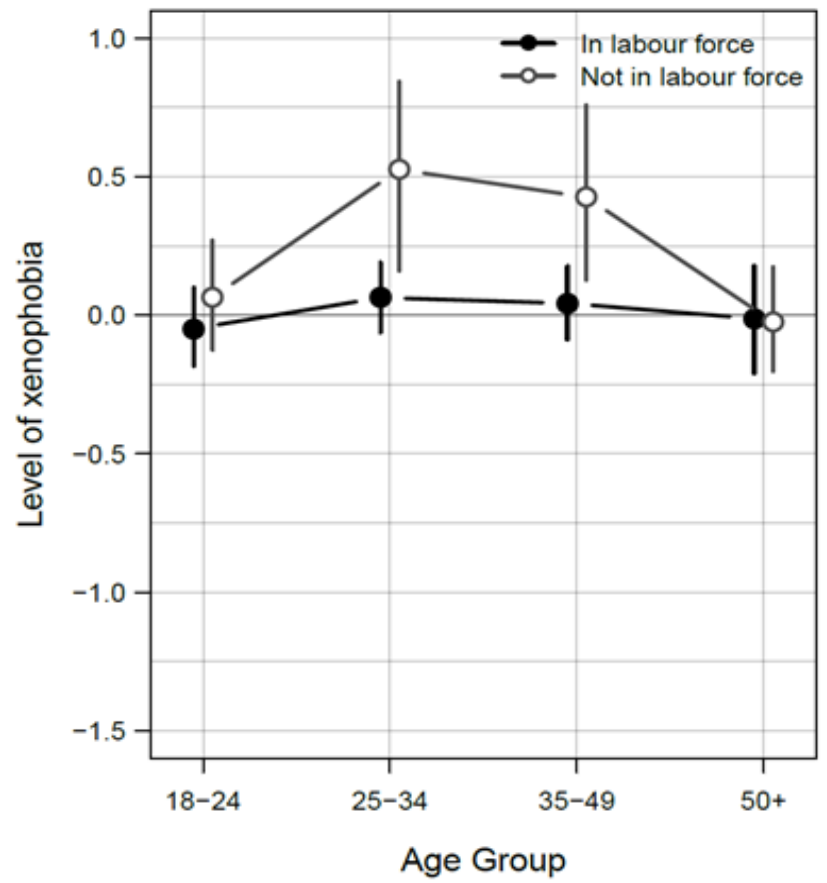

White respondents

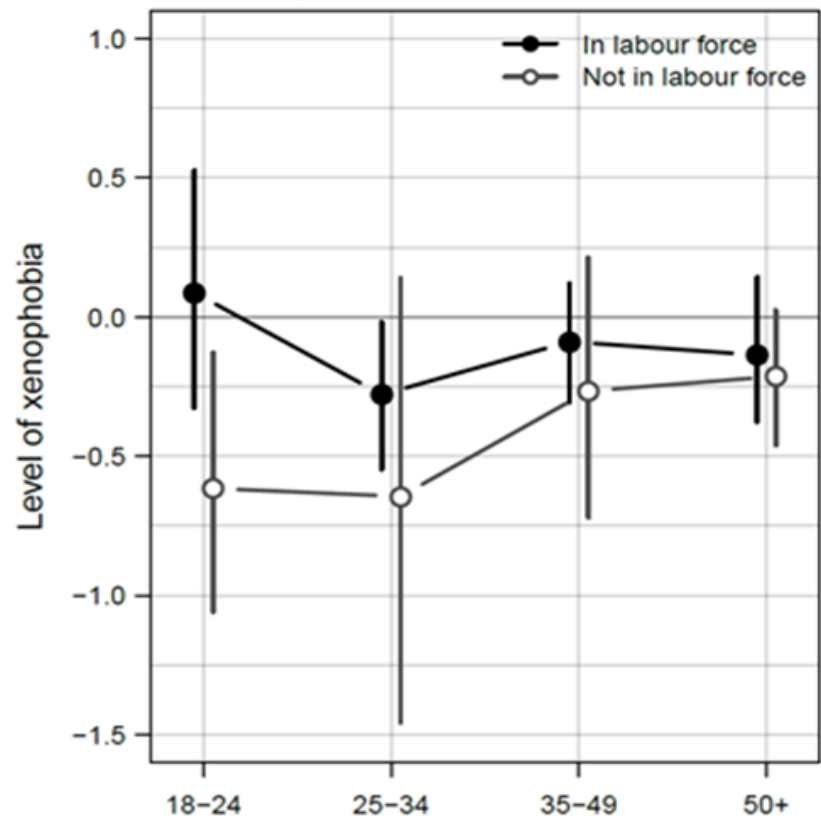

Age Group

Predicted levels of xenophobia for each labor force-by-age combination indicated with points - filled points for respondents in the labor force and hollow points otherwise. Left panel shows the effects for blacks, right panel the effects for whites. All variables other than age and labor-force status held at their means, medians, or modes. Vertical bars show bootstrapped $95 \%$ prediction intervals.

Another way of testing the effects of labor-market competition on xenophobia is to examine the effects of education, because post-secondary education would endow individuals with valuable labor-market skills and thus reduce competition with African immigrants. Returning to the results of Table 2, we see that respondents in the full sample with less than primary education or with completed secondary education are significantly more hostile to immigrants than the most educated respondents, who are the omitted category (models 1 and 3). Whilst the xenophobia of respondents with less than primary education is possibly also a function of increased parochialism and intolerance toward outsiders associated with the lowest levels of education (Lipset, 1960), the elevated xenophobia of those with completed secondary education strongly suggests competition for employment.

The municipal-level measures of unemployment and both the individual- and municipal-level measures of informal housing show no relationship with xenophobia. Nor is the size of the African immigrant community as a percentage of the municipal population associated with xenophobia.

\section{Poverty}

Table 3 shows the tests of the poverty hypothesis. The degree of lived poverty experience is associated with higher levels of xenophobia in the full and black samples. This effect is not found among white respondents - although the variance of this variable is limited here, with only $32 \%$ of white respondents reporting having experienced any form of poverty in the previous year, compared with $83 \%$ of black respondents. 
Table 3: The effects of poverty on xenophobia

\begin{tabular}{|c|c|c|c|c|c|c|c|c|c|}
\hline & Model 1 & Model 2 & Model 3 & Model 4 & Model 5 & Model 6 & Model 7 & Model 8 & Model 9 \\
\hline \multirow{2}{*}{$\begin{array}{l}\text { Sample: } \\
\text { Other covariates: }\end{array}$} & \multicolumn{3}{|c|}{ Full } & \multicolumn{3}{|c|}{ Black } & \multicolumn{3}{|c|}{ White } \\
\hline & Basic & Basic & All & Basic & Basic & All & Basic & Basic & All \\
\hline Afrobarometer lived poverty Index & $.13^{* * *}$ & $.06 * *$ & .03 & $.13^{* * *}$ & $.06^{*}$ & .06 & -.15 & $-.20 *$ & $-.22 *$ \\
\hline & $(.02)$ & $(.02)$ & $(.03)$ & $(.03)$ & $(.03)$ & $(.03)$ & $(.09)$ & $(.09)$ & $(.10)$ \\
\hline Economic evaluations & & $\begin{array}{c}-.33^{* * *} \\
(.04)\end{array}$ & $\begin{array}{c}-.33 * * * \\
(.05)\end{array}$ & & $\begin{array}{c}-.33 * * * \\
(.05)\end{array}$ & $\begin{array}{c}-.35 * * * \\
(.06)\end{array}$ & & $\begin{array}{r}-.21^{*} \\
(.10)\end{array}$ & $\begin{array}{c}.01 \\
(.12)\end{array}$ \\
\hline Total municipal poverty rate & $\begin{array}{c}.00 \\
(.01)\end{array}$ & $\begin{array}{c}.01 \\
(.01)\end{array}$ & $\begin{array}{c}.03 \\
(.04)\end{array}$ & & & & & & \\
\hline Black municipal poverty rate & & & & $\begin{array}{l}-.01 \\
(.02)\end{array}$ & $\begin{array}{l}-.01 \\
(.02)\end{array}$ & $\begin{array}{l}.01 \\
(.03)\end{array}$ & & & \\
\hline White municipal poverty rate & & & & & & & $\begin{array}{l}-.12 \\
(.07)\end{array}$ & $\begin{array}{l}-.12 \\
(.07)\end{array}$ & $\begin{array}{l}-.31 \\
(.18)\end{array}$ \\
\hline Akaike Information Criterion & 1704.58 & 1648.82 & 1771.12 & 1031.59 & 1000.59 & 1104.25 & 328.41 & 328.71 & 420.25 \\
\hline$N$ respondents & 2399 & 2399 & 2399 & 1534 & 1534 & 1534 & 413 & 413 & 413 \\
\hline$N$ municipalities & 185 & 185 & 185 & 157 & 157 & 157 & 54 & 54 & 54 \\
\hline Variance of municipal intercepts & .02 & .02 & .02 & .02 & .02 & .01 & .03 & .03 & .03 \\
\hline Variance of residuals & .09 & .09 & .09 & .11 & .11 & .10 & .06 & .06 & .05 \\
\hline
\end{tabular}

${ }^{* * *} p<0.001,{ }^{* *} p<0.01,{ }^{*} p<0.05$. Standard errors in parentheses. All variables standardized to range from 0 to 1. 
Subjective evaluations have an even stronger effect: Respondents who perceive past, present, and future economic hardship for themselves and the nation as a whole are much more likely to hold and express xenophobic attitudes. Indeed, including this variable reduces the effect of having experienced poverty considerably - to insignificance when all other independent variables are included. This pattern of results suggests that economic evaluations mediate the effects of poverty on xenophobia. To confirm this suspicion, I tested the effects of lived poverty in a model with economic evaluations as the dependent variable and the other basic demographics as controls. Lived poverty has a very substantial negative effect on economic evaluations (the coefficient is -0.21 , with a standard error of 0.01 ). A Sobel test confirms this mediating role played by economic evaluations. ${ }^{20}$

The proportion of households living in poverty in each municipality shows no relationship with respondents' levels of xenophobia.

\section{Relative deprivation}

The individual-level measure of personal relative deprivation shows inconsistent effects on xenophobia (Table 4). Because this survey item is drawn from the same battery as the items used to measure economic evaluations, it is preferable to control for the latter to remove the effects of general evaluations. Thus models 2 and 4 , which include all other independent variables and use the full and black samples, show significant positive effects: Individuals who feel deprived relative to other South Africans exhibit greater xenophobic aggression.

\section{Table 4: The effects of relative deprivation on xenophobia}

\begin{tabular}{|c|c|c|c|c|c|c|}
\hline \multirow{3}{*}{$\begin{array}{l}\text { Sample: } \\
\text { Other covariates: }\end{array}$} & Model 1 & Model 2 & Model 3 & Model 4 & Model 5 & Model 6 \\
\hline & \multicolumn{2}{|c|}{ Full } & \multicolumn{2}{|c|}{ Black } & \multicolumn{2}{|c|}{ White } \\
\hline & Basic & All & Basic & All & Basic & All \\
\hline \multirow[t]{2}{*}{ Evaluations of personal relative deprivation } & $-.02 * *$ & $.02 * *$ & -.01 & $.03 * *$ & -.03 & -.03 \\
\hline & $(.01)$ & $(.01)$ & $(.01)$ & $(.01)$ & $(.02)$ & $(.02)$ \\
\hline \multirow[t]{2}{*}{ Municipal intergroup inequality } & -.02 & $-.03 *$ & -.02 & -.03 & .01 & -.10 \\
\hline & $(.01)$ & $(.01)$ & $(.02)$ & $(.02)$ & $(.05)$ & $(.08)$ \\
\hline \multirow[t]{2}{*}{ Municipal income inequality } & .00 & -.00 & & & & \\
\hline & $(.01)$ & $(.02)$ & & & & \\
\hline \multirow[t]{2}{*}{ Black municipal income inequality } & & & .00 & .01 & & \\
\hline & & & $(.02)$ & $(.02)$ & & \\
\hline \multirow[t]{2}{*}{ White municipal income inequality } & & & & & -.03 & .20 \\
\hline & & & & & $(.06)$ & $(.16)$ \\
\hline Akaike Information Criterion & 1735.83 & 1771.12 & 1059.82 & 1104.25 & 340.34 & 420.25 \\
\hline$N$ respondents & 2399 & 2399 & 1534 & 1534 & 413 & 413 \\
\hline$N$ municipalities & 185 & 185 & 157 & 157 & 54 & 54 \\
\hline Variance of municipal intercepts & .02 & .02 & .02 & .01 & .03 & .03 \\
\hline Variance of residuals & .09 & .09 & .11 & .10 & .06 & .05 \\
\hline
\end{tabular}

${ }^{* * *} p<0.001,{ }^{* *} p<0.01,{ }^{*} p<0.05$. Standard errors in parentheses. All variables standardized to range from 0 to 1 .

\footnotetext{
${ }^{20}$ Test statistic $=7.72, p<0.001$. These tests are conducted using the results from the full sample, but the results within the black and white subsamples are very similar.
} 
In contrast, neither of the contextual measures of income inequality shows any effects. Intergroup inequality is barely significant in the full sample, but the effect is negative, which is contrary to the hypothesis. Income inequality also has no discernable relationship with xenophobia, whether measured using income data for the whole municipal population or just the black or white sub-populations in the area.

\section{Frustration with government}

The government performance evaluations scale shows significant negative relationships with xenophobia in most of the models reported in Table 5. Respondents who have a negative view of government performance, in other words, have elevated levels of xenophobia. This pathway to xenophobia is, however, largely limited to the white sample, with an insignificant effect in the black sample when additional control variables are used.

The reverse pattern is observed with the measure of external political efficacy. Xenophobia is associated with respondents who feel that they do not have a "voice" - that government, at either the national or local levels, does not listen. This effect, while robust in the black sample, does not hold at all in the white sample.

Finally, the actual provision of government services in the respondents' municipalities, in contrast, is not associated with levels of xenophobic aggression.

Table 5: The effects of frustration with government on xenophobia

\begin{tabular}{|c|c|c|c|c|c|c|}
\hline \multirow{3}{*}{$\begin{array}{l}\text { Sample: } \\
\text { Other covariates: }\end{array}$} & Model 1 & Model 2 & Model 3 & Model 4 & Model 5 & Model 6 \\
\hline & \multicolumn{2}{|c|}{ Full } & \multicolumn{2}{|c|}{ Black } & \multicolumn{2}{|c|}{ White } \\
\hline & Basic & All & Basic & All & Basic & All \\
\hline \multirow[t]{2}{*}{ Evaluations of govt performance } & $-.24 * * *$ & $-.13 * *$ & $-.16 * *$ & -.05 & $-.46 * * *$ & $-.41 * *$ \\
\hline & $(.05)$ & $(.05)$ & $(.06)$ & $(.06)$ & $(.12)$ & $(.13)$ \\
\hline External political efficacy & $\begin{array}{c}-.10 * * * \\
(.03)\end{array}$ & $\begin{array}{c}-.12 * * * \\
(.03)\end{array}$ & $\begin{array}{c}-.12 * * * \\
(.03)\end{array}$ & $\begin{array}{c}-.14 * * * \\
(.03)\end{array}$ & $\begin{array}{c}.03 \\
(.07)\end{array}$ & $\begin{array}{l}.02 \\
(.07)\end{array}$ \\
\hline Municipal services provision & $\begin{array}{l}-.02 \\
(.01)\end{array}$ & $\begin{array}{l}-.04 \\
(.03)\end{array}$ & & & & \\
\hline Black municipal services provision & & & $\begin{array}{l}-.00 \\
(.02)\end{array}$ & $\begin{array}{l}-.04 \\
(.02)\end{array}$ & & \\
\hline \multirow[t]{2}{*}{ White municipal services provision } & & & & & -.16 & -.18 \\
\hline & & & & & $(.33)$ & $(.50)$ \\
\hline Akaike Information Criterion & 1684.68 & 1771.12 & 1029.12 & 1104.25 & 319.36 & 420.25 \\
\hline$N$ respondents & 2399 & 2399 & 1534 & 1534 & 413 & 413 \\
\hline$N$ municipalities & 185 & 185 & 157 & 157 & 54 & 54 \\
\hline Variance of municipal intercepts & .02 & .02 & .02 & .01 & .03 & .03 \\
\hline Variance of residuals & .09 & .09 & .11 & .10 & .05 & .05 \\
\hline
\end{tabular}

${ }^{* * *} p<0.001,{ }^{* *} p<0.01,{ }^{*} p<0.05$. Standard errors in parentheses. All variables standardized to range from 0 to 1 .

\section{Social mobilization}

Mobilization by other community members is associated with xenophobic attitudes (Table 6). Echoing the findings of Misago (2012), the results show that attendance at community meetings is positively related to xenophobia. Including the general political participation scale reduces this meeting-attendance effect - unsurprisingly given the correlation between the two variables 
Table 6: The effects of mobilization on xenophobia

\begin{tabular}{|c|c|c|c|c|c|c|c|c|c|}
\hline & Model 1 & Model 2 & Model 3 & Model 4 & Model 5 & Model 6 & Model 7 & Model 8 & Model 9 \\
\hline \multirow{2}{*}{$\begin{array}{l}\text { Sample: } \\
\text { Other covariates: }\end{array}$} & \multicolumn{3}{|c|}{ Full } & \multicolumn{3}{|c|}{ Black } & \multicolumn{3}{|c|}{ White } \\
\hline & Basic & Basic & All & Basic & Basic & All & Basic & Basic & All \\
\hline \multirow[t]{2}{*}{ Community meeting attendance } & $.05^{* * *}$ & .03 & .02 & $.06^{* *}$ & .03 & .03 & .05 & .04 & .02 \\
\hline & $(.01)$ & $(.02)$ & $(.02)$ & $(.02)$ & $(.02)$ & $(.02)$ & $(.04)$ & $(.04)$ & $(.04)$ \\
\hline \multirow[t]{2}{*}{ Political participation } & & $.10^{* *}$ & $10^{* * *}$ & & $.11^{* *}$ & $.12^{* * *}$ & & .06 & .09 \\
\hline & & $(.03)$ & $(.03)$ & & $(.04)$ & $(.04)$ & & $(.10)$ & $(.11)$ \\
\hline \multirow[t]{2}{*}{ Opposition share municipal seats } & .00 & .01 & .01 & .01 & .01 & .02 & -.03 & -.03 & -.02 \\
\hline & $(.01)$ & $(.01)$ & $(.02)$ & $(.02)$ & $(.02)$ & $(.02)$ & $(.04)$ & $(.04)$ & $(.05)$ \\
\hline \multirow[t]{2}{*}{ Partisan identity: ANC } & -.01 & -.01 & .01 & -.02 & -.02 & -.00 & .10 & .10 & .11 \\
\hline & $(.02)$ & $(.01)$ & $(.02)$ & $(.02)$ & $(.02)$ & $(.02)$ & $(.08)$ & $(.08)$ & $(.08)$ \\
\hline \multirow[t]{2}{*}{ Partisan identity: opposition } & -.00 & -.00 & .02 & -.02 & -.03 & -.01 & $.10^{* *}$ & $.10^{* *}$ & $.09^{* *}$ \\
\hline & $(.02)$ & $(.02)$ & $(.02)$ & $(.03)$ & $(.03)$ & $(.03)$ & $(.03)$ & $(.03)$ & $(.03)$ \\
\hline \multirow[t]{2}{*}{ Daily news consumption } & -.03 & -.03 & -.01 & -.03 & -.03 & -.02 & .08 & .08 & .03 \\
\hline & $(.02)$ & $(.02)$ & $(.02)$ & $(.02)$ & $(.02)$ & $(.02)$ & $(.06)$ & $(.06)$ & $(.06)$ \\
\hline Akaike Information Criterion & 1744.40 & 1741.32 & 1771.12 & 1063.32 & 1060.19 & 1104.25 & 340.10 & 344.49 & 420.25 \\
\hline$N$ respondents & 2399 & 2399 & 2399 & 1534 & 1534 & 1534 & 413 & 413 & 413 \\
\hline$N$ municipalities & 185 & 185 & 185 & 157 & 157 & 157 & 54 & 54 & 54 \\
\hline Variance of municipal intercepts & .02 & .02 & .02 & .02 & .02 & .01 & .04 & .04 & .03 \\
\hline Variance of residuals & .09 & .09 & .09 & .11 & .11 & .10 & .05 & .05 & .05 \\
\hline
\end{tabular}

${ }^{* * *} p<0.001,{ }^{* *} p<0.01,{ }^{*} p<0.05$. Standard errors in parentheses. All variables standardized to range from 0 to 1. 
- so we report the effects of meeting attendance both with (models 2, 5, and 8) and without the participation scale (models 1, 4, and 7). Political participation, in turn, also shows a positive effect: Those who report taking part in protests, strikes, and other forms of collective action are more likely to report a willingness to take part in anti-immigrant collective action. Once again, the effects vary across race: This pattern of social mobilization is not present in the white sample, with neither of the variables showing significant effects.

Despite xenophobic comments from prominent South African leaders in the years before and after the 2008 attacks, respondents who read, listen to, or watch the news every day do not show heightened levels of xenophobia. ${ }^{21}$ There does, however, appear to be some relationship between partisan mobilization and xenophobia, at least for white respondents. Whites who support opposition parties are significantly more xenophobic than whites who do not support any party. The effect is of the same magnitude for white ANC supporters, but the small number of these supporters means that the effect is not significant. If we combine ANC and opposition supporters and compare them to political independents, we find that supporting a political party - of whatever stripe - is associated with greater white xenophobia. There is no effect of party support in the other samples. Nor does the intensity of local electoral competition, as captured by the opposition party share of municipal seats, have an impact on levels of xenophobia. ${ }^{22}$

\section{Symbolic threat}

Studies of xenophobia in the developed world have highlighted the important role played by symbolic threats to one's national identity. This finding does not appear to generalize to the South African case (Table 7). The effects of national identification are weak - being significant only in the full sample - and negative, which is the opposite direction to that implied by the hypothesis. The hypothesis would also predict that symbolic threat, and thus xenophobia, increases as ingroups become more culturally distinct from the outgroup. Yet being a minority group member has, if anything, a slightly negative effect on xenophobia.

Table 7: The effects of symbolic threat on xenophobia

\begin{tabular}{|c|c|c|c|c|c|c|}
\hline & Model 1 & Model 2 & Model 3 & Model 4 & Model 5 & Model 6 \\
\hline \multirow{2}{*}{$\begin{array}{l}\text { Sample: } \\
\text { Other covariates: }\end{array}$} & \multicolumn{2}{|c|}{ Full } & \multicolumn{2}{|c|}{ Black } & \multicolumn{2}{|c|}{ White } \\
\hline & Basic & All & Basic & All & Basic & All \\
\hline Strength of national identity & $\begin{array}{r}-.08^{*} \\
(.03)\end{array}$ & $\begin{array}{l}-.06 \\
(.03)\end{array}$ & $\begin{array}{l}-.05 \\
(.05)\end{array}$ & $\begin{array}{l}-.05 \\
(.05)\end{array}$ & $\begin{array}{l}-.02 \\
(.08)\end{array}$ & $\begin{array}{c}.04 \\
(.08)\end{array}$ \\
\hline Race: Asian & $\begin{array}{l}-.01 \\
(.04)\end{array}$ & $\begin{array}{l}-.05 \\
(.04)\end{array}$ & & & & \\
\hline Race: Coloured & $\begin{array}{r}-.06^{*} \\
(.02)\end{array}$ & $\begin{array}{r}-.05^{*} \\
(.03)\end{array}$ & & & & \\
\hline Race: White & $\begin{array}{c}-.07^{* * *} \\
(.02)\end{array}$ & $\begin{array}{l}-.05 \\
(.03)\end{array}$ & & & & \\
\hline Akaike Information Criterion & 1729.07 & 1771.12 & 1041.62 & 1104.25 & 329.05 & 420.25 \\
\hline$N$ respondents & 2399 & 2399 & 1534 & 1534 & 413 & 413 \\
\hline$N$ municipalities & 185 & 185 & 157 & 157 & 54 & 54 \\
\hline Variance of municipal intercepts & .02 & .02 & .02 & .01 & .03 & .03 \\
\hline Variance of residuals & .09 & .09 & .11 & .10 & .06 & .05 \\
\hline
\end{tabular}

${ }^{* * *} p<0.001,{ }^{* *} p<0.01,{ }^{*} p<0.05$. Standard errors in parentheses. All variables standardized to range from 0 to 1 .

\footnotetext{
${ }^{21}$ In additional analyses not shown here, I find that there is no evidence of any interactive effect between news exposure and party support.

${ }^{22}$ I also verified that there is no interactive effect between the municipal strength of opposition parties and party support; there is not.
} 
Moreover, when poverty and unemployment are controlled for (Model 2), there are no significant differences between the levels of xenophobia expressed by black South Africans and the levels expressed by their white and Asian compatriots. Coloured South Africans still exhibit lower levels of xenophobia than black South Africans, although this effect is substantively small.

\section{Discussion and conclusion}

This paper examines mass xenophobia in South Africa. Existing research on this topic has, for the most part, focused on developing and advancing theoretical explanations. This paper instead attempts to test which of these theories, if any, do indeed account for xenophobic attitudes. Table 8 summarizes the results by hypothesis, explanatory variable (rows), and sample (columns).

Although competition over jobs and government housing is perhaps the most frequently cited explanation for South African xenophobia, the evidence is mixed. Having postsecondary education reduces xenophobia, and disengagement from the labor market while in the prime working years increases xenophobia, although only for black respondents. In contrast, the theory of mobilization by one's social and community networks, which is largely neglected in existing studies, ${ }^{23}$ finds considerable support in these data. Both political participation and attendance at community meetings are associated with elevated xenophobia.

The bulk of the supportive evidence corresponds, however, to the theories of absolute deprivation, relative deprivation, and frustration with government. Both the personal experience of poverty and negative evaluations of economic conditions are associated with increased xenophobia, with evaluations mediating the effects of poverty on xenophobia. Evaluations of personal deprivation relative to other South Africans are similarly linked with xenophobic aggression. And, among the black majority, a perception that government is inattentive produces increased xenophobia, with negative evaluations of government performance having a similar effect for the white minority.

It is noteworthy that none of the contextual, municipal-level variables proves to have significant associations with xenophobia. On the one hand, this may simply reflect the fact that these contextual variables are all objective economic and political indicators. The individual-level results demonstrate that subjective evaluations are far more powerful predictors of xenophobia than objective conditions. Economic evaluations, for example, have a much more powerful effect on xenophobia than lived poverty, and indeed appear to mediate whatever effect is exerted by the respondent's actual level of poverty.

On the other hand, the absence of any municipal effects may be due to municipalities being fairly large and diverse geographic districts. The metropolitan municipalities, where most of the recorded incidents of xenophobic violence have occurred, are particularly heterogeneous. It would be fruifful for future research to consider the effects of more finelygrained contexts. Unfortunately, it would require considerably more effort to combine survey data with South African geographies smaller than local municipalities, as their boundaries and names fluctuate over time.

All the theories for which support was found in this study - absolute deprivation, relative deprivation, and frustration with government - rely upon a frustration-aggression mechanism. Being poor, in an absolute or a relative sense, and perceiving government to be distant, inattentive, or ill-performing all conceivably produce feelings of frustration. The effects of being disengaged from the labor market, but within prime working age, which I advanced as a test of the labor market competition hypothesis, also would appear to involve frustration.

${ }^{23}$ The notable exception being Misago (2012). 
Table 8. Summary of theories, variables, and results

\section{Resource competition}

Labor market status

Level of education

Unemployment rate in municipality

Lives in informal vs. formal housing

Percent informal housing in municipality

Log percent municipal population born elsewhere in Africa

\section{Poverty}

Lived poverty experience

Poverty rate in municipality

Evaluations of personal and national economic conditions

\section{Relative deprivation}

Evaluations of personal relative deprivation

Vertical inequality in municipality

Horizontal inequality in municipality

\section{Frustration with government performance}

Municipal supply of electricity and water services

Evaluations of government performance

External political efficacy

\section{Mobilization}

Meeting attendance

Participation in unconventional political action

Opposition share of municipal seats

Partisan identity

Daily news exposure (radio, TV, newspapers, or Internet)

Symbolic threat

Strength of national identity

Minority race group

$\checkmark$ significant effect, in the direction hypothesized, in the model with all control variables

$\dagger$ labor force non-participation has significant effect conditional on race and age

$\ddagger$ meeting attendance has significant effect without participation variable

In addition, the frustrations that accompany all these factors - poverty, relative deprivation, poor government performance, no employment prospects - are not directed at the responsible party, which is plausibly the government in all cases. Rather, South Africans appear to direct their aggression at African immigrants, both attitudinally and behaviorally. The bulk of the evidence presented in this paper thus points toward immigrants being treated as scapegoats for the failings of government. 
To some extent, the potential remedies for xenophobia are economic. If poverty and unemployment were reduced, and the economic outlook generally improved, the models used in this paper imply that there would be a commensurate reduction in xenophobia. Such an economic revival would of course have beneficial effects far beyond the issue of xenophobia - it has been the stated ambition of every ANC government since 1994, but has thus far proved to be elusive.

However, the determinants of xenophobia are also political, and thus more readily within the grasp of South Africa's leaders. If government were more concerned for its citizens and performed its local service delivery roles more effectively, then the models also predict a decline in xenophobia. In particular, the prominence of public perceptions of government that it is performing poorly and is inattentive - in the findings of this paper suggests that South African leaders could readily make improvements, and thus begin to drain the swamp of xenophobia. 


\section{References}

Bonacich, E. (1976). Advanced capitalism and black/white race relations in the United States: A split labor market interpretation. American Sociological Review, 4(1), 34-51.

Centre for the Study of Violence and Reconciliation. (2008). Understanding current xenophobic attacks and how South Africa can move forward. Presentation, Parliamentary Seminar on Migration and Xenophobia, Cape Town, 20 June 2008.

Charman, A., \& Piper, L. (2012). Xenophobia, criminality and violent entrepreneurship: Violence against Somali shopkeepers in Delft South, Cape Town, South Africa. South African Review of Sociology, 43(3), 81-105.

Claassen, C. (2014). Who participates in communal violence? Survey evidence from South Africa. Research \& Politics, 1(1). Online only. http://journals.sagepub.com/doi/pdf/10.1177/2053168014534649.

Claassen, C. (2016). Group entitlement, anger and participation in intergroup violence. British Journal of Political Science, 46(1), 127-148.

Crush, J. (2001). The dark side of democracy: Migration, xenophobia and human rights in South Africa. International Migration, 38(6), 103-133.

Dambrun, M., Taylor, D. M., McDonald, D. A., Crush, J., \& Méot, A. (2006). The relative deprivationgratification continuum and the attitudes of South Africans toward immigrants: A test of the V-curve hypothesis. Journal of Personality and Social Psychology, 91(6), 1032-1044.

Dancygier, R. M. (2010). Immigration and conflict in Europe. Cambridge: Cambridge University Press.

Dodson, B. (2010). Locating xenophobia: Debate, discourse, and everyday experience in Cape Town, South Africa. Africa Today, 56(3), 2-22.

Dollard, J., Miller, N. E., Doob, L. W., Mowrer, O. H., \& Sears, R. R. (1939). Frustration and aggression. New Haven, CT: Yale University Press.

Essa, A. (2015). Is South Africa taking xenophobia seriously? Al Jazeera Online, 30 April 2015. http://www.aljazeera.com/blogs/africa/2015/04/south-africa-xenophobia150430224826901.html.

Essa, A., \& Patel, K. (2015). South Africa and Nigeria spar over xenophobic violence. Mail \& Guardian Online, 28 April 2015. http://mg.co.za/article/2015-04-28-south-africa-and-nigeria-sparover-xenophobic-violence.

Everatt, D. (2010). Overview and prospects. In D. Everatt (Ed.), South African Civil Society and Xenophobia. Johannesburg: Strategy \& Tactics.

Fauvelle-Aymar, C., \& Segatti, A. (2012). People, space and politics: An exploration of factors explaining the 2008 anti-foreigner violence in South Africa. In L. B. Landau (Ed.), Exorcising the Demons Within: Xenophobia, Violence and Statecraft in Contemporary South Africa (pp. 58-89). Johannesburg: Wits University Press.

Gelman, A., \& Hill, J. (2007). Data analysis using regression and multilevel/ hierarchical models. New York, NY: Cambridge University Press.

Gurr, T. R. (1970). Why men rebel. Princeton, NJ: Princeton University Press.

Hall, J. (2015). Anti-foreigner violence exposes festering conflict in South Africa. Africa Conflict Monitor, 71-77.

Harris, B. (2001). A foreign experience: Violence, crime and xenophobia during South Africa's transition. Violence and Transition Series, Vol. 5. Centre for the Study of Violence and Reconciliation, Johannesburg.

Hickel, J. (2014). 'Xenophobia' in South Africa: Order, chaos, and the moral economy of witchcraft. Current Anthropology, 29(1), 103-127. 
Horowitz, D. (2011). The deadly ethnic riot. Berkeley, CA: University of California Press.

Hovland, C. I., \& Sears, R. R. (1940). Minor studies of aggression: VI. Correlation of lynchings with economic indices. Journal of Psychology, 9(2), 301-310.

Huckfeldt, R., Beck, P. A., Dalton, R. J., \& Levine, J. (1995). Political environments, cohesive social groups, and the communication of public opinion. American Journal of Political Science, 39(4), 1025-1054.

Huddy, L., \& Sears, D. O. (1995). Opposition to bilingual education: Prejudice or the defense of realistic interests? Social Psychology Quarterly, 58(2), 133-143.

Human Sciences Research Council. (2008). Citizenship, violence and xenophobia in South Africa: Perceptions from South African communities. Democracy and Governance Programme, HSRC, Pretoria.

Landau, L. B. (2011). Loving the alien? Citizenship, law, and the future in South Africa's demonic society. African Affairs, 109(435), 213-230.

Landau, L. B. (2012). Introducing the demons. In L. B. Landau (Ed.), Exorcising the Demons Within: Xenophobia, Violence and Statecraft in Contemporary South Africa (pp. 1-25). Johannesburg: Wits University Press.

Lipset, S. M. (1960). Political man. Garden City, NY: Doubleday.

Mattes, R., Taylor, D. M., McDonald, D. A., Poore, A., \& Richmond, W. (1999). Still waiting for the barbarians: SA attitudes to immigrants and immigration. Migration Policy Series No. 14. Southern African Migration Project and Idasa. http://samponline.org/wpcontent/uploads/2016/10/Acrobat14.pdf.

McAdam, D. (1986). Recruitment to high-risk activism: The case of Freedom Summer. American Journal of Sociology, 92(1), 64-90.

McLaren, L. M. (2003). Anti-immigrant prejudice in Europe: Contact, threat perception, and preferences for the exclusion of migrants. Social Forces, 81(3), 909-936.

Sniderman, P. M., Hagendoorn, L., \& Prior, M. (2004). Predisposing factors and situational triggers: Exclusionary reactions to immigrant minorities. American Political Science Review, 98(1), 3549.

Misago, J. P. (2012). Disorder in a changing society: Authority and the micro-politics of violence. In L. B. Landau (Ed.), Exorcising the Demons Within (pp. 90-108). Johannesburg: Wits University Press.

Misago, J. P., Monson, T., Polzer, T., \& Landau, L. B. (2010). May 2008 violence against foreign nationals in South Africa: Understanding causes and evaluating responses. Johannesburg: Consortium for Refugees and Migrants in South Africa and University of the Witwatersrand.

Monson, T., \& Arian, R. (2012). Media memory: A critical reconstruction of the May 2008 violence. In L. B. Landau (Ed.), Exorcising the Demons Within (pp. 26-55). Johannesburg: Wits University Press.

Morris, A. (1998). 'Our fellow Africans make our lives hell': The lives of Congolese and Nigerians living in Johannesburg. Ethnic and Racial Studies, 21(6), 1116-1136.

Neocosmos, M. (2006). From "foreign natives" to "native foreigners": Explaining xenophobia in postapartheid South Africa. Monograph Series, Council for the Development of Social Science Research in Africa, Dakar.

Nieftagodien, N. (2012). Xenophobia's local genesis: Historical constructions of insiders and the politics of exclusion in Alexandra Township. In L. B. Landau (Ed.), Exorcising the Demons Within (pp. 109-134). Johannesburg: Wits University Press.

Nyar, A. (2010). What happened? A narrative of the May 2008 xenophobic violence. In D. Everatt (Ed.), South African Civil Society and Xenophobia (p. 7). Johannesburg: Strategy \& Tactics. 
Olzak, S. (1992). The dynamics of ethnic competition and conflict. Stanford, CA: Stanford University Press.

Parliament of the Republic of South Africa. (2008). Report of the task team of members of Parliament probing violence and attacks on foreign nationals.

Runciman, W. G. (1966). Relative deprivation and social justice: A study of attitudes to social inequality in twentieth-century England. Berkeley, CA: University of California Press.

Sherif, M. (1966). In common predicament: Social psychology of intergroup conflict and cooperation. Boston, MA: Houghton Mifflin.

Snow, D. A., Zurcher, L. A. Jr., \& Ekland-Olson, S. (1980). Social networks and social movements: A microstructural approach to differential recruitment. American Sociological Review, 45(5), 787-801.

South African Human Rights Commission. (2010). Report on the SAHRC investigation into issues of rule of law, justice and impunity arising out of the 2008 public violence against nonnationals.

Southern African Migration Project. (2008). The perfect storm: The realities of xenophobia in contemporary South Africa. Migration Policy Series No. 50. With Idasa.

Steinberg, J. (2008). South Africa's xenophobic eruption. Institute for Security Studies Paper 169. Institute for Security Studies, Johannesburg. 


\section{Recent Afrobarometer working papers}

No. 172 Logan, Carolyn. 800 languages and counting: Lessons from survey research across a linguistically diverse continent. 2017

No. 171 Guardado, Jenny \& Leonard Wantchekon. Do electoral handouts affect voting behavior? 2017.

No. 170 Kerr, Nicholas \& Anna Lührmann. Public trust in elections: The role of media freedom and election management autonomy. 2017.

No. 169 McNamee, Lachlan. Indirect colonial rule and the political salience of ethnicity. 2016.

No. 168 Coulibaly, Massa. Measuring democracy in Africa: Applying anchors. (French). 2016

No. 167 Monyake, Moletsane. Does personal experience of bribery explain protest participation in Africa? 2016.

No. 166 Robinson, Amanda Lea. Ethnic diversity, segregation, and ethnocentric trust in Africa. 2016.

No. 165 Hounsounon, Damas. Décentralisation et qualité de l'offre de services socio-publics en Afrique subsaharienne. 2016

No. 164 Mattes, Robert \& Mulu Teka. Ethiopians' views of democratic government: Fear, ignorance, or unique understanding of democracy? 2016.

No. 163 Manacorda, Marco \& Andrea Tesei. Liberation technology: Mobile phones and political mobilization in Africa. 2016.

No. 162 Albaugh, Ericka A. Language, education, and citizenship in Africa. 2016.

No. 161 De Kadt, D., \& Evan S. Lieberman. Do citizens reward good service? Voter responses to basic service provision in southern Africa. 2015

No. 160 Aquino, J. A. The effect of exposure to political institutions and economic events on demand for democracy in Africa. 2015

No. 159 Tsubura, Machiko. Does clientelism help Tanzanian MPs establish long-term electoral support? 2015

No. 158 Claire, Adida L., Karen E. Ferree, Daniel N. Posner, \& Amanda L. Robinson. Who's asking? Interviewer coethnicity effects in African survey data. 2015

No. 157 Bratton, Michael \& E. Gyimah-Boadi. Political risks facing African democracies: Evidence from Afrobarometer. 2015

No. 156 Croke, Kevin, Guy Grossman, Horacio A. Larreguy, \& John Marshall. Deliberate disengagement: How education decreases political participation in electoral authoritarian regimes. 2015

No. 155 Bleck, Jaimie \& Kristin Michelitch. On the primacy of weak public service provision in rural Africa: Malians redefine 'state breakdown' amidst 2012 political crisis. 2015

No. 154 Leo, Benjamin, Robert Morello, \& Vijaya Ramachandran. The face of African infrastructure: Service availability and citizens' demands. 2015

No. 153 Gottlieb, Jessica, Guy Grossman, \& Amanda Lea Robinson. Do men and women have different policy preferences, and if so, why? 2015

No. 152 Mattes, Robert \& Samantha Richmond. Are South Africa's youth really a 'ticking time bomb'? 2015

No. 151 Mattes, Robert. South Africa's emerging black middle class: A harbinger of political change? 2014

No. 150 Cheeseman, Nic. Does the African middle class defend democracy? Evidence from Kenya. 2014 


\section{$A=B^{\prime}$

\section{Afrobarometer Working Papers Series}

Editor: Michael Bratton, mbratton@msu.edu

Editorial Board: E. Gyimah-Boadi, Carolyn Logan, Robert Mattes, Leonard Wantchekon

Afrobarometer publications report the results of national sample surveys on the attitudes of citizens in selected African countries toward democracy, markets, civil society, and other aspects of development. Afrobarometer publications are simultaneously co-published by the six Afrobarometer Core Partner and Support Unit Institutions. All Afrobarometer publications can be searched and downloaded from www.afrobarometer.org.

Support for Afrobarometer is provided by the UK's Department for International Development (DFID), the Mo Ibrahim Foundation, the Swedish International Development Cooperation Agency (SIDA), the United States Agency for International Development (USAID), and the World Bank.

\section{Core partners:}

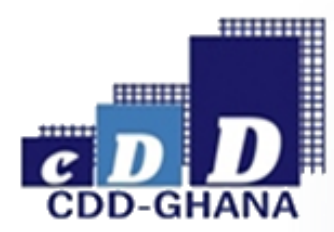

Center for Democratic Development (CDD-Ghana)

95 Nortei Ababio Street, North Airport Residential Area

P.O. Box LG 404, Legon-Accra, Ghana

Tel: +23321 776142

Fax: +23321 763028

www.cddghana.org
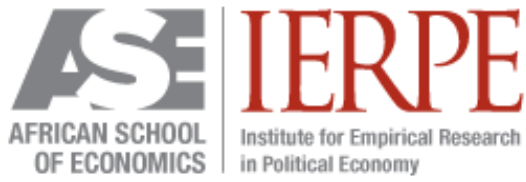

Institute for Empirical Research in Political Economy (IREEP) Arconville, Lot 104 - Parcelle J, 02 BP: 372, Cotonou, Republique du Benin

Tel: +229 21363 873/ 22994940108

Fax: +229 21362029

www.ireep.org

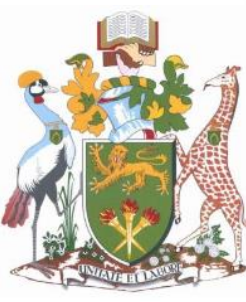

Institute for Development Studies (IDS), University of Nairobi

P.O. Box 30197, Nairobi, 00100, Kenya

Tel: +254 202247968

Fax: +254 202222036

www.ids.uonbi.ac.ke

\section{Support units:}

\section{MICHIGAN STATE U N I V E R S I T Y}

Michigan State University (MSU) Department of Political Science East Lansing, MI 48824, USA Tel: +1 517353 6590; Fax: +1 5174321091 www.polisci.msu.edu

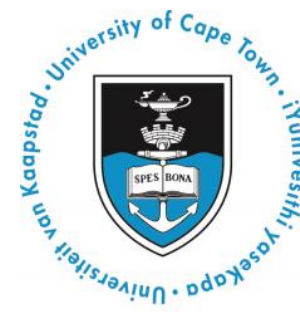

University of Cape Town (UCT) Institute for Democracy, Citizenship and Public Policy in Africa Leslie Social Science Building Rondebosch, Cape Town, WC 7701 South Africa Tel: +27216503827
Institute for Justice and Reconciliation (IJR) 105 Hatfield Street, Gardens, 8001, Cape Town, South Africa

Tel: +27 217637128

Fax: +27 217637138

www.ijr.org.za 